Badr Aziz and Bruno S. Sergi

\title{
The push towards a modern economy: The Skolkovo innovation centre and IT as a way of reforming Russia's economic strategy1
}

\begin{abstract}
The authors of this article refer to the prospects for Russia's Skolkovo innovation centre. It is believed by many that this project will match California's Silicon Valley when completed. The main aim of the article is to highlight the economic impact this project will have on the Russian economy and how this mega project will help Russia to shift its dependence from its natural resources of oil and natural gas to other key factors, such as IT, innovation and technological projects. In the past, Russia has been heavily reliant on oil and natural gas, which had been the major core of the economy. However, things have become a little more complex, in particular in Europe, but at global level. Hence, the new situation demands that Russia looks for alternative means to get its economy going instead of relying on oil and natural gas as it has been doing over the past several years.
\end{abstract}

Keywords: natural resources, FDI, IT, technology transfer, economic change, globalisation

Introduction

Russia is a market and an export-oriented economy. In this context, we want to look at the case of Skolkovo and how this 'modern' city will bring employment, development and prosperity to the country. Russia has the tenth largest population in the world, of $142 \mathrm{~m}$ people. It has a $\$ 2.5 \mathrm{tr}$ economy and a growth rate which has fluctuated quite rapidly. Unemployment has been around the 5.4-6\% mark. It is ranked $41^{\text {st }}$ out of 43 countries in the European region, and its overall score is below the global average. Its economy is ranked 140 th in the 2014 Index of Economic Freedom. It does not have a booming market economy, like Turkey or China, although its main source of growth in the last few years, i.e. during the first two terms of Vladimir Putin's presidency, has been the oil and gas industry. Nevertheless, it needs to find alternative sources in order to be able to make rapid progress in the changing landscape of the global economy.

The article Russia faces economy trap as oil decline looms points out that:

Oil and natural gas account for almost 70 percent of exports and about half of budget revenue.

1 The authors would like to thank the Editor and the Associate Editor for their careful reading of our original draft and their many insightful comments and suggestions, as well as their constructive comments, which have helped us improve the final version of this manuscript. 
This was fine for a while, but things have changed which require a drastic solution. According to the article Enduring slow down of growth threatens Russian economy:

Russia to be able to come out of this complex situation, it has to create a competitive strategy, free from any political shortsighted and corrupt management.

With this in mind, this article looks at modern Russia and states that Russia needs to focus on other key areas in order to get its economy growing, such as innovation, $\mathrm{R} \& \mathrm{D}$ and technological projects and also as a means of job creation. In this direction, Russia has been working on a new project to create a technological city, like Silicon Valley in San Francisco, called the Skolkovo innovation centre. This provides the core focus for this article.

\section{Background to Skolkovo and the project}

First of all, it is important to establish Skolkovo's geographic location. Skolkovo is a village in the Odintsovsky district of Moscow Oblast. It is about $2 \mathrm{~km}$ from the Setun River, with a very small population estimating at around 1500 , according to the GeoNames geographical database. In 2010, Dmitry Medvedev, then Russian President, decided to launch a project to create Skolkovo innovation centre, with the major aim of setting-up a scientific hub for innovation and research in Russia. Many are hopeful that Skolkovo will be a planned high technology business area some $20 \mathrm{~km}$ west of central Moscow. The Russian government is, essentially, hoping to found a city replica of Silicon Valley in San Francisco.

An article on the BBC website, Russia creates its own Silicon Valley, describes the main features of what this project will bring to the table, pointing out that:

Skolkovo will have some important attractions. Tax breaks and other funding will be offered to selected companies.

This would indicate that the Russian government is highly focused and determined to make this city a centre of technological growth and development. Hence, allowing foreign companies to invest here is a positive move and will push the economy in the right direction. However, at the same time it must be noted that, despite these optimistic aims of the Russian government, i.e. of allowing foreigners to come and invest in the region, progress in this direction has been minimal, particularly given that the major foreigners who are very keen in investing in Russia are Americans. Due to the political disputes between the US and Russia, it is likely to take time for any significant level of investment to be made.

\section{Russia and its reliance on oil and natural gas}

The BBC article goes on to state:

Rising oil prices have helped the government increase tax revenue in the past, but future economic growth depends on the government investing these huge one-off oil revenues into a larger economic growth scheme. 
This would clearly suggest that Russia's economic policy of depending on its oil and gas reserves had served it well in the past but that, now things are changing dramatically and with new technological progress being made around the world, Russia needs to create a new strategy and a new economic policy. That is to focus more on innovation and technological projects. Hence, the idea of making an innovation centre in Skolkovo is a significant step and will demand major levels of investment.

Furthermore, according to a case study from the University of Pennsylvania Skolkovo: A case study in government-supported innovation reports that:

The abundance of natural resources - such as oil, gas, coal and timber - and the economy's resulting dependence on these commodities for export earnings have led to a natural resource curse, whereby most public and private capital is funneled to support those industries, at the expense of nearly all other sectors of the economy.

This would indicate that Russia has been heavily dependent on its natural resources such as fossil fuels. Hence, it has neglected other important aspects which could have helped move the economy forwards. The Russian government is hopeful that, with the completion of Skolkovo, things will get back on track.

According to an older report from ZAAB Energy:

Russia is one of the world's leading countries in terms of oil production and oil reserves. It has strong macroeconomic fundamentals. Its investment climate is constantly improving as evidenced by Russia's investment grade ratings by rating agencies. Russia has a highly skilled work force in particular in the oil and gas sector. Since 1998 the Russian oil industry showed impressive growth rates and was the driving industry for Russian economic growth. An increase in development drilling is expected to stimulate further production growth which is anticipated to reach 565 million tons in 2010. Ninety percent (90\%) of the fuel and energy market in the Russian Federation is controlled by nine vertically integrated companies. The remaining market is left to independent oil and gas companies.

This precisely sums up Russia's dependence on oil and natural gas: it will take some time for the Russian economy to divert itself from these natural resources and be able to adopt a different strategy. Indeed, in reality, it would be significant if Russia was able to reduce its dependence on its natural resources and look for alternative resources; nevertheless, it does not seem apparent that Russia will be able to change that quickly to an alternative source in the near future.

An article by Alec Luhn asserts:

While the Kremlin-connected billionaires next door all made fortunes off Russia's natural resources, the implicit goal of the Skolkovo innovation hub is to move the country's economy away from oil and oligarchs by jump-starting the tech startup industry. Allegations of corruption, construction delays and political conflicts have plagued the project, but it has nevertheless continued to amass resident companies and further investment.

But the jury is out on whether Skolkovo will be able to stimulate Russia's entrepreneurial environment - and justify an estimated \$5.4 billion in government spending. 
This article demonstrates that Russia has realised the reality that it cannot totally rely on natural resources for its development. Hence, as the article suggests, Russia is moving from the old path of dependency on fossil fuels towards adopting a strategy of utilising technology to its advantage. However, it also identifies that there are major hurdles for Russia in corruption, political conflicts and construction delays. All these indicate some of the elements which may derail Russia's ambition to establish the innovation centre.

\section{Figure 1 - Trends in Russia's natural gas production}

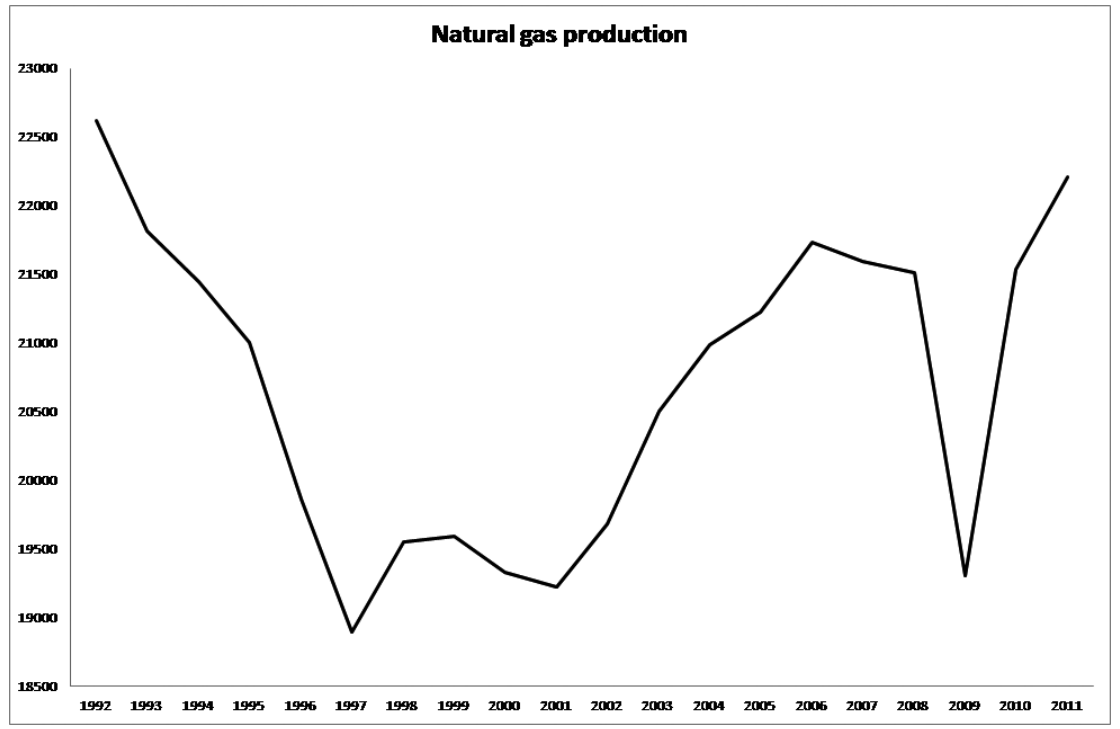

Table 1 - Russian natural gas exports, 2010-2050, in reference scenario

$\begin{array}{lccrrr} & \mathbf{2 0 1 0} & \mathbf{2 0 2 0} & \mathbf{2 0 3 0} & \mathbf{2 0 4 0} & \mathbf{2 0 5 0} \\ \text { Europe } & 6.6 & 8.2 & 8.7 & 9.6 & 11.5 \\ \text { Asia } & 0.5 & 0.8 & 1.3 & 2.1 & 3.4 \\ \text { America } & - & 0.3 & 0.3 & 0.3 & 0.4 \\ \text { Total } & 7.1 & 9.3 & 10.4 & 12.0 & 15.3\end{array}$

Source: Paltsev (2011)

By looking at the statistical data, we can clearly see how much Russia has been dependent on oil and natural gas in years gone by. Table 1 shows that Russian exports to Asia and Europe will increase over the next few decades which, in itself, proves that Russia's dependence on oil and natural gas is not going to dissipate that quickly. Sergi (2011) points out:

Russia has also benefited greatly from high oil and gas prices during the past decade, and the increasing flow of resources coming to the country's budget has been coupled with considerable foreign direct investment. FDI has greatly benefited Russia, but it has passed its peak. 
This supports the point that Russia has neglected other aspects of its economy which could have given it a considerable boost.

\section{Corruption and transparency challenges in Russia}

On the issue of corruption, Transparency International's Corruption Perception Index ranked Russia in $127^{\text {th }}$ position out of 177 countries in 2013 . The Index scores countries and territories on a scale from 0 (highly corrupt) to 100 (very clean). No country has a perfect score and two-thirds of them score below 50.

At the same time, the World Bank's Ease of Doing Business Index ranked Russia in $111^{\text {th }}$ and $92^{\text {nd }}$ places in 2012 and 2013, respectively. The relevant website explains:

Economies are ranked on their ease of doing business, from 1-189. A high ranking on the ease of doing business index means the regulatory environment is more conducive to the starting and operation of a local firm. This index averages the country's percentile rankings on 10 topics, made up of a variety of indicators, giving equal weight to each topic. The rankings for all economies are benchmarked to June 2013.

Table 2 - Corruption Perceptions Index, 2013

\begin{tabular}{|l|l|c|}
\hline Rank & Country & Score \\
\hline 1 & Denmark & 91 \\
\hline 2 & New Zealand & 91 \\
\hline 3 & Finland & 89 \\
\hline 5 & Singapore & 86 \\
\hline 9 & Australia & 81 \\
\hline 12 & Germany & 78 \\
\hline 127 & Russia & 28 \\
\hline
\end{tabular}

Source: Transparency International 
Table 3 - Ease of Doing Business Index, 2012 and 2013

\begin{tabular}{|l|c|c|}
\hline \multirow{2}{*}{ Country } & \multicolumn{2}{|c|}{ Ranking } \\
\cline { 2 - 3 } & $\mathbf{2 0 1 2}$ & $\mathbf{2 0 1 3}$ \\
\hline Afghanistan & 170 & 164 \\
\hline Albania & 82 & 90 \\
\hline Argentina & 121 & 126 \\
\hline Bangladesh & 132 & 130 \\
\hline Brazil & 118 & 116 \\
\hline Canada & 17 & 19 \\
\hline China & 99 & 96 \\
\hline France & 35 & 38 \\
\hline Russian Federation & 111 & 92 \\
\hline Norway & 7 & 91 \\
\hline South Africa & 41 & \\
\hline
\end{tabular}

Source: World Bank

These are some of the economic indicators for Russia in the past year. It will have to clear some of these hurdles for it to inject sufficient confidence such that it starts to attract investment into Russia from the international community.

It must be noted that, if we look at Russia from the perspective of corruption and the ease of doing business, there are indeed certain elements within the Russian government who will have their own certain agenda and will want to disrupt the construction of the Skolkovo project. There is also the possibility that certain political forces may want to gain a bigger share of the pie in the completion of the Skolkovo project in terms of getting more revenue and having a much greater control over the project. Hence, Russian politics does not inspire that much confidence in the meantime.

\section{An investment alternative to Russia's dependence on natural resources}

In terms of what Russia could do in terms of adopting a different strategy, a focus on innovation, technology, etc. is, perhaps, an obvious alternative. The article Russia's policymakers need a long-term vision for economic growth refers to what Russia can focus on which, in the long-run, will help bring a fresh change to its economy, commenting thus:

A new vision for Russia has to start from here, nurturing innovative and productive potential along the way. The country benefits from huge natural reserves, and whatever the price level or levels may be, the country will enjoy this ongoing export status for long periods ahead and far into the future as well. Thus, the next step is fathoming the deep and crucial relationship 
between domestic investment in $R \& D$ as an engine for economic growth and such elements as FDI, labor intensity, and labor productivity.

This presents a goal for Russia to aim for in the forthcoming years. It should invest in $R \& D$, education, innovation, etc. Hence, the creation of Skolkovo will present an opportunity for Russia to be able to enhance economic growth and reduce its dependency on its natural resources.

Additionally, the University of Pennsylvania's case study, which we have already quoted above, also comments appositely here:

However, private investment in early-stage business projects in Russia is still about US\$300 million per year, roughly 1/70 th that of similar investment in the US. According to the Global Entrepreneurship Monitor, only about 5\% of the Russian adult population is engaged in earlystage entrepreneurship, the lowest level among countries with a comparable GDP per capita.

This shows that Russia has been behind most countries in terms of its investment in entrepreneurial activity. But it hopes that, with the completion of Skolkovo, Russia will be able to make more rapid progress in such investment projects.

Moreover, Russia's attempt to change itself will not be at all easy. Having been so heavily dependent on its natural resources for such a long time, it seems clear that many Russians do not want change, especially as regards a diversion of its reliance on the natural resources which have been the backbone of the economy for a good part of the last twenty years. Some tough decisions will have to be made if this ambitious change is to have a chance of being successful. However, in the current political environment, this does not look likely.

\section{Russia's standing in the IT sector}

Information Technology (IT) has been a sector that has caught the eye of the world with the advances in technology in the past few years, and many countries have started to focus their attention on the IT sector. Analysts consider IT to provide a suitable economic alternative to the fossil fuels which, in the past decade or so, have been used as source of economic development.

Russia has taken its time in adapting to the new developments which other economies are currently experiencing. Statistically speaking, the IT sector in Russia has not reached the heights as seen in the US, UK or Germany. According to the 2011 IT industry competitiveness index, Russia was ranked $46^{\text {th }}$, just behind Bulgaria in 43rd and Turkey in 41 st. More recently, the Global Competitiveness Index 2013-2014 ranks Russia in $64^{\text {th }}$ place. This is a clear indictor that IT had not been an area on which Russia had focused.

However, in recent times there have been signs that Russia has begun to show progress in the IT sector. The Business Software Alliance says that:

IT infrastructure has been the area of greatest improvement for Russia since the previous study, with its category ranking rising two places to $36^{\text {th }}$. Broadband subscriptions have risen, driven by better infrastructure and demand for social networking services. 
Elena Wilson Rowe has an article in the Journal of Eurasian Studies which comments:

In many ways, a pleasant, modern infrastructure was seen as fundamental to attracting the kind of human capital that the Skolkovo project required. For example, Viktor Vekselberg, Russian businessman and head of the Skolkovo Fund, argued that Skolkovo will be 'a city that is comfortable for work, life and relaxation - an example of the city of the future' (in Blagoveshenskiy, 2010). Vice-President of the Skolkovo Fund, Stanislav Naumov, forwards a vision of not only Skolkovo's infrastructure but also its residents (in Zykova, 2012).

Hence, this sends a very clear message that the Skolkovo project is envisaged as being of great success which will enable Russia to attain new heights in terms of innovation and technology.

Indeed, the Global Competitiveness Report 2013-14 documents the immense improvements that Russia is making in the IT sector, with increases in the sector responsible for helping to push the Russian economy into an upwards spiral:

The Russian Federation, in $64^{\text {th }}$ place, improves by three positions since last year. The country's macroeconomic environment has continued to improve - up from $44^{\text {th }}$ two years ago to $19^{\text {th }}$ this year-because of low government debt and a government budget that has maintained a surplus. Other strengths include its high level of education enrolment, especially at the tertiary level; its fairly good infrastructure; and its large domestic market (8th), all of which represent areas that can be leveraged to improve Russia's competitiveness.

Wilson Rowe comments that the establishment of the Skolkovo project was accompanied by the inculcation of high profile links:

Head of the Skolkovo Fund, Russian oligarch Viktor Vekselberg, in describing Skolkovo Innovation Centre's educational cooperation with MIT, felt it necessary to underline that 'From the very outset, we have insisted that this will be a Russian university with the possibility of active cooperation with specialists from other Russian institutes of higher education.'

This implies that, with the Skolkovo project, Russia has been able to extend its reach to MIT, a world-renowned university known for its scientific, engineering and technological education and research. Hence, joint co-operation with MIT is likely to allow Russian education and technological growth to flourish. This may well be one of the great successes and outcomes of this project in the long-run: Russian students will gain valuable exposure and experience, both of which are absolutely required in $21^{\text {st }}$ century labour markets.

Moreover, having foreigners come into Russia and invest here will provide an immense boost to the Russian economy. This will mean a flow of money into the country that will help put the country's budget into surplus. 


\section{Economic prospects of the Skolkovo project for Russia}

Rebecca Grant talks in her article about the economic prospects brought by the completion of Skolkovo, reporting that:

Skolkovo Foundation president Viktor Vekselberg said he expects to raise more than $\$ 11$ billion in private investment by 2020 and that Skolkovo will not need government financing after 2025. He also predicted that this 'innovation city' will contribute \$6.5 billion to Russia's economy over that time period, and he ultimately hopes it will add \$45 billion to national GDP.

This is the right step taken by Russia; investing in a mega project will help to deliver a much needed boost to an economy which has been struggling for a while.

In terms of what else can this project bring, Monty Munford points to Viktor Vekselberg's views on the impact on jobs of such a level of added economic activity:

Skolkovo is already running nearly 1,000 startups and has created 12,000 highly-skilled jobs. By its contribution to GDP growth, each job of this kind equals to 10 'ordinary' jobs and is a huge contribution to President Putin's recently announced program to create 25 million Russian jobs by 2020.

This is a good sign for the Russian economy as the Skolkovo project will help to create more highly-skilled jobs in the future.

In terms of the economic prospects of this project, it is apparent that most of these jobs will be available for highly-skilled people. Most Russians are not that qualified, or else do not possess the kinds of skills which are being brought by the technological project at Skolkovo. Hence, the prospect of creating new jobs for many Russians comes as great news for Russia and as, in the long-run, human capital is a critical input for growth - the knowledge economy and knowledge are strictly inter-related, as is the knowledge-growth relationship - an overall project which is aimed at improving human capital could, thereby, reduce inequality and make growth more inclusive. However, this might constitute a mere mirage for most of Russia as long as the benefits from Skolkovo are not spread right across this vast country.

\section{Skolkovo and technological prospects for Russia}

Commentators seem convinced that, in the long-run, Russia should try to focus its attention on the IT and innovation sector. According to the Institute of Contemporary Development:

Undoubtedly, Russia's natural resource sector has played a significant role in its achievement. However, economic growth based solely on the natural resources sector is neither sufficient nor sustainable. We are entering the era of the global information society, where knowledge is the core resource and mechanism of accelerated development. Russia's continued economic growth will depend on the successful development of the innovative industries of the nation's economy, particularly innovative infrastructure.

This presents a clear case for what Russia should do in the forthcoming period: i.e. focus its time, energy and financial resources on the innovation and development sector. 
The Institute of Contemporary Development carries on:

The advanced development of high-tech industries, including the Information and Communication Technology Sector (ICT), is also a key condition for a strong and growing economy. In most developed countries, ICT represents 8-12\% of a country's GDP and is one of the leading sectors in terms of capitalization of the global economy. This sector's role will only strengthen with time. Alongside oil \& gas, Russia's ICT is one of the two drivers of economic development. Since 2000, this sector has developed four times faster than the average performance of the Russian economy. ICT has demonstrated rapid, steady and stable growth in all of its segments. The implementation of a number of key national projects and other large-scale government programs will also encourage the development of innovative industries.

This is what Russia should be aiming for and it will present a new opportunity for the economy to expand and grow in the future.

The aims behind the establishment of the Skolkovo innovation centre is to encourage change in the economy via promoting the transfer of technology from around the world and bringing innovation into the country. According to Steiner (2013):

The most important function of the center is to promote technology transfer from around the world, thereby stimulating innovation and entrepreneurship in Russia. The Skolkovo Foundation hopes that, ultimately, the new center will help modernize Russia's economy, transforming it from an economy based on natural resources to one based on innovation and scientific development.

Consequently, the Russian government should be given the credit for making a conscious effort to shift its reliance from its natural resources to innovation and scientific development. Steiner goes on to refer to the key aims in more detail, pointing out the potential prospect that this mega project can bring to the Russian economy is of change, both for good and for better:

The Russian Skolkovo Innovation Center outside Moscow - the Russian Federation's attempt to approximate if not duplicate the success of California's Silicon Valley - is a vehicle for worldwide technology transfer to Russia in the areas of information technology, biomedicine, energy, satellite and space technology, and nuclear technology. These five clusters are critical to the Russian Federation's program of economic modernization away from reliance on the oil and gas industry.

Steiner also explains that Russia's mindset is changing with the passage of time regarding the prospect of using alternative measures, arguing that the Skolkovo project will help Russia in meeting the challenges it will face in the future and provide a positive spark to its economy:

Russia recognizes the need to diversify and accelerate non-energy industries. With up to $30 \%$ of Russia's GDP and half of all government revenue derived from hydrocarbons, reliance on energy creates serious challenges over the next several decades as global supplies and consumption patterns change. Investments in technology research programs like Skolkovo are a clear sign that at least some parts of government are eager to develop solutions which could offset reductions in the energy industry. 
Furthermore, the Russian government is investing a significant amount of financial resources in this project, in the hope that it will achieve its aims of changing the future of the Russian Federation. The international weekly journal Science reported back in 2010 that the Russian government had launched the project with 85 billion roubles (\$2.6bn) in state funding until the end of 2014. Science went on to report in its 13 August 2013 issue that:

On 1 August, the government announced that it intends to put a further 135.6 billion roubles into the venture by 2020. Focusing on five areas - information technology, nuclear technology, energy efficiency, biomedical innovation, and space and telecommunications - Skolkovo is the boldest of Russia's efforts to spur high-tech innovation and reduce the country's economic dependence on exports of oil, gas and minerals.

There is considerable potential for the Russian IT industry. The website To Russia with Ease comments that:

The Information Technology market in Russia is growing dynamically as much as 50\% per annum. The advanced development of high-tech industries is a key feature of the strong and growing economy of the country. The strategy for the development of Russia's information society is a top priority as it serves as a basis for the development of the innovation economy. 2010 was a year of recovery from the crisis for the IT market that grew up by approximately 30 percent that comes to be a positive trend, yet there is still potential for growth.

The Saint Petersburg International Economic Forum 2014 agrees that one important thing on which Russia must focus is the establishment of a workforce which can handle the IT industry and help create new jobs with the expansion of the IT industry.

Its website argues:

The future development of the IT sector in Russia is largely dependent upon the creation of a workforce that is capable of capitalizing on the strategic capabilities of technologies on the global market. Information technology forms an integral part of almost every industry, and as technology continues to become more sophisticated, it creates new markets.

Figure 3 reports that Russia's current IT spending is low but, nevertheless, it is growing fast. If the appropriate structural changes are made, and Russia manages to get its IT sector up and running, Russia's economy could be changed for the better. The main objectives in the enhancement of Russia's IT sector might be described, in line with Russian Facts and Figures as:

Developing high-performance, application-oriented computing systems to improve the efficiency and quality of information services.

Develop a modern social and industrial information infrastructure.

Slowly, and with the passage of time, we can see that Russia is making the right decisions to make its economy more oriented toward IT rather than oil. Indeed, this is the major goal of the Russian government in the years to come. According to an article on Bloomberg - 'Russia to Double IT Exports to \$11 Billion to Cut Oil Dependence': 
Russia aims to more than double its information technology exports to $\$ 11$ billion by 2020 to decrease the economy's dependence on commodities, according to a strategy drafted by the Telecommunications Ministry. Russian IT exports are approaching \$5 billion this year, Deputy Minister Mark Shmulevich said in an interview in Moscow. 'It's a meaningful figure, compared with the country's arms export of about $\$ 15$ billion,' he said. 'It shows that Russia has competitive IT products to offer.' Russia plans to help its domestic IT companies compete with global technology companies such as Google Inc., Facebook Inc. and Microsoft Corp. (MSFT), which are expanding in the country, the strategy shows.

Figure 2 below looks at the Growth Competitiveness Index (GCI), which aims to quantify the quality of a country's macroeconomic environment, the state of its public institutions and its level of technological readiness, including as regards IT and technological growth. This shows the reality that Russia still lags far behind the other developed and more technologically advanced countries as regards its IT sector. More ground needs to be covered and hard decisions need to be made.

Figure 2 - Economic Competitiveness Rating 2014: Russia compared to the continent

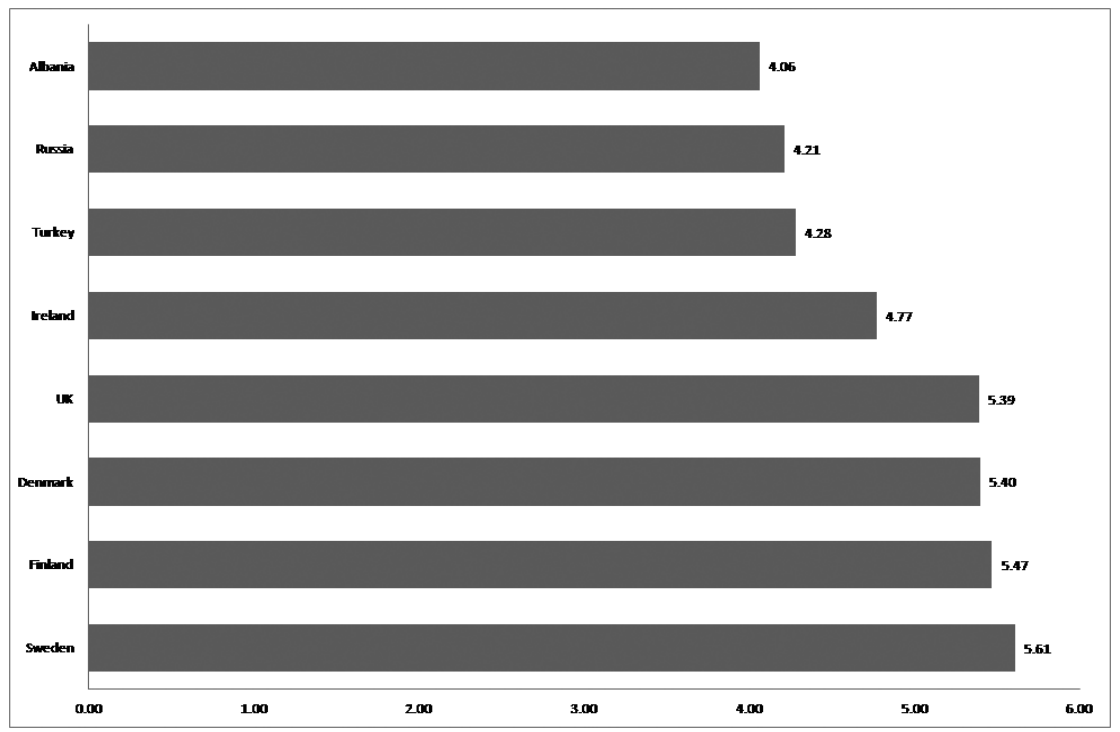

Source: World Economic Forum, 2014

Here, note that higher competitiveness scores are more desirable:

- Very high: 5.51 to 7.00

- High: 4.51 to 5.50

- Moderate: 3.51 to 4.50

- Low: 3.01 to 3.50

- Very low: 0.0 to 3.00 . 
From Figure 2, we can deduce that Russia's economic competitiveness, in terms of the level which its technological progress has reached, and with particular reference to the IT sector, can be classified as moderate. This depicts that Russia has a long way to go for it to be able to enhance its technological growth, especially in the IT sector.

The Skolkovo project is assumed likely to bring an immense boost to the IT sector, as the Russian government is seeking, and it may deliver the rewards being sought in terms of providing new dimensions to the Russian economy as a whole. At this point, the signs are good and credit must be given for those making such hard and bold decisions. Pulya (2012) points out in this context that:

\begin{abstract}
The Skolkovo project is just one way the government has ramped up its support of the sector over the past two to three years. An increasing number of state agencies are now accessible online; various information projects have begun, and the state has stepped up its war against pirated property and commercial raids. Moreover, the government has talked of developing online media and the commercial operation of fourth-generation networks. State-sponsored industrial parks are emerging, and the government has introduced special economic zones that have reduced taxation and other benefits.
\end{abstract}

With Skolkovo the basis for a thriving IT sector in the future, this will help attract foreign investors into Russia. According to Henni (2012):

Subsidies and tax cuts for foreign investors in hi-tech hubs are helping to attract funding for new businesses. Russian start-ups and business incubators are thriving and attracting the attention of foreign technology investors. Tiger Global Management, a New York-based international investment management firm has recently invested twice in the Russian e-commerce platform Wikimart.ru - \$5m (£3.1m) in 2010 and another $\$ 7 m$ in 2011.

This very positive sign of the interest of foreign investors will boost the economy and will also help Russia in the transfer of technology and also to improve its competitiveness on a global scale.

It is encouraging to see progress being made on the Russian side on IT and in the area of technological growth. However, the numbers would show a completely different story on these two elements: Russia still has much distance to travel and many hurdles to overcome before it can meet the demands and changes of an ever-changing global economy. Progress has been apparent, but more work needs to be done.

\title{
The current debate
}

Let us now take a specific look at what is being omitted in the current debate regarding Russia; namely, the creation of the conditions for the prosperous and sustained growth which results from increasing levels of inter-dependence within a regional and multi-polar global context. During the past eleven years, Russia has witnessed enormous social and economic change - a fact which has left no-one in doubt. The world economy is increasingly interconnected by way of trade, finance and labour migration flows that, quite logically, are affecting the Russian economy these days. This reality also interconnects stock exchanges, currencies, global companies, technology 
spillovers, etc., making Russia more vulnerable to global economic turbulence and vicissitudes.

This specific reality, at the domestic and the international level, should drive our analysis. For example, we have a specific issue regarding the European sovereign debt crisis and its after-effects, which caused a heavy sell-off in the Russian stock market, leading the MICEX index to fall 17\% during the first ten days of August 2011.

Following the disintegration of the Soviet Union in the early 1990s, the Russian stock market has been either among the best performing or worst performing markets in the world, according to an analysis by Renaissance, a Moscow-based investment bank. This is, therefore, evidence that the Russian economy is a huge cyclical market which Russian policy-makers will have to confront in the long-run.

Rising oil prices have helped the government increase tax revenue in the past, but future economic growth depends on the government investing these huge one-off oil revenues into a larger economic growth scheme: it should not be indefinitely building up the Reserve Fund. Unless the economy is transformed into a real engine of growth, it is truly possible that the country will remain trapped and vulnerable to a drop in oil prices at all times.

The situation calls for important and timely decisions to build the foundation for a sustainable, positive and stable future. The earlier debate among economic experts was simply on whether to focus more on oil and gas as a source of budgetary policy stability, but the larger issue of directing and realising new economic growth was not addressed. This so-called debate was kept within cosy academic circles, with most experts absent from the discussions for whatever reason. Consequently, the possibility to provide a realistic recipe for necessary economic growth was then lost.

Importantly, and highly related to this larger debate, it must be added and stressed as well that the hydrocarbon market is relevant for Russia and its growth both at the present moment and into the future. It is ever more momentous and important to think now in terms of how to attain rational and well-sustained growth for today and especially for future, long-term, success.

What is needed is a proactive growth strategy, which should form the centrepiece of the country's programme for economic growth and sustainability. A series of economic measures has been partly realised in the past, but much of what we prefer to call realistic sustainability has not so far been achieved. Specifically, we refer here to the need for Russian economic policy-makers to move away from their short-term mentality towards a broader, long-term vision of economic growth. Moreover, this needs to be a vision that follows the trend, which is already evident, of multi-polarity in the global economy.

In this context, a recent analysis was made by the World Bank (2011), which ranked countries in terms of their influence on global and regional growth. These rankings are used as a means of identifying when an economy is capable of significantly driving growth at global and regional levels. Russia was identified as a key 'regional growth pole' in eastern Europe and central Asia from 2004 to 2008 (ahead of Turkey and the Czech Republic). Being a 'current growth pole' nation means that a country has spillover effects that create growth at the regional level. 
Put simply, Russia's policy-makers have to think realistically and realise that their country is not, at this time, a driver of global growth. It has, however, been a significant driver at the regional level. A new vision for Russia has to start from here, nurturing innovative and productive potential along the way. The country benefits from huge natural reserves and, whatever the price level or levels may be, the country will enjoy this ongoing export status for long periods ahead and far into the future as well. Thus, the next step is to fathom the deep and crucial relationship between domestic investment in R\&D, as an engine for economic growth, and such elements as FDI, labour intensity and labour productivity.

In this context, it has been reported widely that the ability to develop innovative capacity and greater demand at home is the key to economic growth at larger and more fundamental levels. This means, in the main, relying on greater speed determinants and related, but specific, benchmarking to realise actual technological breakthroughs, stimulate adoption/innovation and the diffusion of technologies, and improve the efficiency of capital. To put it simply, it should raise total factor productivity. Russia must emphasise the importance of a fresh look at the education system, as well as at R\&D as a way of leading towards prosperity and promoting innovation - as is the focus of this article.

These may become a source of Russia's future accelerated economic growth, and this is crucial if the country wants to stay competitive in the long-term; a renewed approach provides more opportunities than threats for entrepreneurs to expand their business opportunities in Russia. In reality, the current international arena has never offered so many opportunities and challenges to individual Russian managers, businesses and the academic community alike. The expansion of markets has created a need for capable managers and modern institutions, and future Russian governments will have to stimulate this process in order to be able to turn it into a success story.

In addition, Russia has seen foreign direct investment shrink dramatically: levels have halved since the economic boom and the result of current downwards pressures is that these are now virtually at a standstill. This is indeed discouraging. However, Russia needs to take resolute action to attract greater levels of foreign investment. Russia's growth is 3-4 percentage points below that seen in the other BRIC countries and major changes must be implemented as part of a long-term agenda. The call to stimulate robust economic growth (in the region of 7\% - which would double GDP in about a decade) might be laudable, but a massive inflow of FDI is unlikely to turn up as long as the country remains sluggish. This is not to say that Russia cannot rely on FDI as an engine of growth. Rather, the country's authorities should attract as many foreign companies as possible in order to bring money and expertise into the country. Now, we must keep in mind that this new growth strategy needs to continue being developed and applied, in the teeth of the worst economic crisis for decades.

\section{Challenges facing the Russian economy}

First, the great challenges facing Russia today are its well-known huge geographical and resource asymmetries, which are complicating factors in any post-economic crisis growth model. That is, there is nothing simple about generating outstanding growth figures. Growth needs solid foundations - it cannot just be plucked out of thin air. 
Russia's economic development policy-makers need to shift the engine of growth away from oil and gas revenues to foreign investment inflows or, rather, from a single origin to a variety of growth sources. However, after a decade-long oil and gas bonanza, Russia is currently facing unprecedented uncertainty over FDI and policy-makers should be aware that FDI is less predictable as a growth engine than natural resources. It might flow into the country - but, then again, it might not. It could transpire that, in the near future or in the long-term, it embraces the country's entire economy or, otherwise, that it simply allows it to make the most of particular assets.

Second, there is no rational reason to bemoan that Russia enjoys the status of an oil-rich country. There are many other countries where oil money was not used to benefit the majority of the population. In particular, we should stop apologising for the use of oil resources for growth. We do not agree that Russia should downplay its energy industry. No-one can say with any great certainty how long this oil revenue will last, but this industry will continue to exist and play a major role for decades to come. Moreover, this sector is strongly intertwined with the broader economy and no-one can belittle the positive aspects of these bonds in the short- or medium-term. What is worse is that the Russian economy would fade away overnight without its oil sector wealth.

Third, policy-makers should build on the reality: this sector is flourishing again and can still take a central position in any modern, revised growth strategy that is developed. Russia will continue to play a role both in western Europe (despite the tensions that have grown in the past few years between the EU and Russia, not least over the EU's plans to liberalise the energy market by 2014) as well as in Asia.

Fourth, an agenda for sustainable economic growth could focus on beefing up several important sectors. Instead of squirreling away up to $10 \%$ of the country's GDP reserve fund, the country could save $5 \%$ of the reserve fund and mobilise the remaining funds for up-and-coming areas of the economy, such as the relationship between science and industry. There is ample evidence of positive linkages between intangible capital investments - i.e. human capital, skills, etc. - and labour productivity growth.

Having said that, what really matters most is that the Russian leaders who are responsible for drawing up and implementing economic growth policies should manage this oil money well, rather than simply overseeing a paradigm shift from 'oil growth' to 'FDI growth'. Russia must act on the basis of a shared understanding of how best to handle these resources, challenges and opportunities in the context of the after-effects of the economic crisis. The keys to this new course of action would be via cutting the toxic practices of corruption and fraud that undermine the system's efficiency and channelling the country's massive oil revenue back into the economy and society.

The hardest part of this new path is to design a dazzling growth plan in which no oil rouble is mis-spent. Russia's economic policy leaders should not think twice about drawing on the country's excellence and natural resources; simply said, without 'Waiting for Godot' to arrive from abroad, and ensuring that they do not leave the country trapped in a catch-22 situation with 'no more oil' and 'no modernity.' Everyone agrees that Russia's recent decade-long oil bonanza will end sometime in the future and the country must look for a long-term, firmly-rooted economic and social improvement. Should Russia make headway with this ambitious development programme, FDI 
would, once again, start flowing into the country, greatly adding to domesticallysparked growth.

\section{Conclusion}

To conclude, the processes of regionalisation and globalisation are continuing to develop; they are changing the rules of the game and require adaptation and innovation, a greater ability to 'catch up' technologically, higher education standards, and institutional reforms. These trends offer extensive opportunities for the development of all current and prospective companies operating in Russia - both domestic and international - but, to be successful, governments and companies have to take the route of continuing innovation. Russia is slowly moving in the right direction, but it will have to safeguard itself against issues related to corruption, transparency and the political disputes which have been present in Russia's history for a while.

The policy prescriptions of our analysis are really two-fold. Firstly, Russia needs to invest heavily in its education system as well as in information technology and innovation (as we have argued throughout this article). It could well be the case that higher oil export tariffs and mineral extraction taxes could help to build the resources in support of Russia's long-term economic growth. Secondly, policy-makers have to develop a vision for long-term economic growth rather than simply focusing on dayto-day issues.

\section{References}

Brin, Sergey (2012) Can Russia create a new Silicon Valley? available at: http:// www.economist.com/node/21558602.

Butler, Declan (2013) Russia pins hope on science city available at: http://www.nature.com/news/russia-pins-hopes-on-science-city-1.13550.

Bord, Eugene and Natalya Guseva (2013) Skolkovo: A case study in government-supported innovation available at: http://knowledge.wharton.upenn.edu/article/ skolkovo-case-study-government-supported-innovation/.

Filatova, Irina (2013) Skolkovo Foundation to get \$15Bln in 2013-2020 available at: http://www.themoscowtimes.com/business/article/skolkovo-foundation-toget-15bln-in-2013-2020/483982.html.

Grant, Rebecca (2013) Russia investing \$4B in 'innovation city’ Skolkovo to inseminate startup culture available at: http://venturebeat.com/2013/08/09/russia-investing-4b-in-innovation-city-skolkovo-to-insemminate-startup-culture/.

Henni, Adrien (2012) Russia's technology boom attracts foreign investors available at: http://www.telegraph.co.uk/sponsored/rbth/technology/9183881/Russia-technology-foreign-investors.html.

Independent Statistics \& Analysis (2014) US Energy Information Administration available at: http://www.eia.gov/countries/country-data.cfm?fips=rs\#ng. 
Luhn, Alec (2013) Not just oil and oligarchs available at: http://www.slate.com/articles/technology/the_next_silicon_valley/2013/12/russia_s_innovation_city_skolkovo_plagued_by_doubts_but_it_continues_to.html.

Lennon, David (2012) Skolkovo makes its pitch in the UK available at: http://rbth.com/ articles/2012/02/20/skolkovo_makes_its_pitch_in_the_uk_14885.html.

Lovasz, Agnes and Henry Meyer (2012) Russia faces economy trap as oil decline looms available at: http://www.bloomberg.com/news/2012-12-13/russia-at-riskfrom-dwindling-oil-reserves-european-bank-says.html.

Munford, Monty (2013) 'Russia's Skolkovo project will have to overcome toxic bureaucracy if it wants to compete with Silicon Valley' Business Insider available at: $\mathrm{http}: / / w w w . b u s i n e s s i n s i d e r . c o m / t h e-f u t u r e-o f-r u s s i a s-s k o l k o v o-i n n o v a t i o n-c e n-$ ter-2013-9.

Makarov, Valentin (2014) Prospects for the Russian IT sector: markets, workforce, strategy available at: http://www.forumspb.com/en/2014/sections/30/materials/ 229/sessions/765.

Morris, Ben (2010) Russia creates its own Silicon Valley available at: http:// news.bbc.co.uk/2/hi/business/8638222.stm.

Paltsev, Sergey (2011) Russia's Natural Gas Export Potential up to 2050 available at: http://web.mit.edu/ceepr/www/publications/workingpapers/2011-012.pdf

Pulya, Vsevolod (2012) Russian IT market faces cloudy future available at: http:// rbth.com/articles/2012/02/01/russian_it_market_faces_cloudy_future_14284.html.

Sergi, Bruno S (2011) Russia's policymakers need a long-term vision for economic growth available at: http://valdaiclub.com/economy/31620.html.

Sergi, Bruno S (2013) Enduring slow down of growth threatens Russian economy available at: http://valdaiclub.com/economy/61405.html.

Schwab, Klaus (2013) Global Competitiveness Report 2013-2014 Full Data Edition, World Economic Forum, available at: http://www3.weforum.org/docs/WEF_GlobalCompetitivenessReport_2013-14.pdf.

Steiner, Eduard (2013) Russia's Skolkovo Innovation Center available at: http://fmso.leavenworth.army.mil/collaboration/cocom/eucom/skolkovo.pdf.

Transparency International (2013) Corruption Perception Index available at: http:// cpi.transparency.org/cpi2013/results/.

World Bank (2011) Multipolarity: The New Global Economy. Global Development Horizons 2011 available at: http://siteresources.worldbank.org/INTGDH/Resources/GDH_CompleteReport2011.pdf

World Bank Ease of Doing Business Index 2014 available at: http://data.worldbank.org/ indicator/IC.BUS.EASE.XQ.

Wilson Rowe, Elena (2014) 'The future, the foreign and the public-private 
divide: Socio-political discourses around Skolkovo' Journal of Eurasian Studies 5(1): 39-47.

World Economic Forum (2014) Economic Competitiveness Rating available at: http:// www.globalpropertyguide.com/Europe/Russia/competitiveness

ZAAB Energy Russian oil and gas facts 2007 available at: http://www.zaabenergy.com/index.php?article_id $=44 \&$ clang $=0$.

\section{Websites:}

Business Software Alliance (BSA) (2011) IT Industry Competitiveness Index, Russia.

Institute of Contemporary Development http://www.insor-russia.ru/en/.

Gartner Global Insight IDC www.idc.com.

Index of Economic Freedom

http://www.heritage.org/index/country/russia

Population of Skolkovo, Russian Federation

http://population.mongabay.com/population/russian-federation/492396/skolkovo

To Russia with Ease http://torussia.org/it_in_russia.

Russia, World Facts and Figures http://worldfactsandfigures.com/countries/russia.php.

UN data: Russian Federation, United Nations Statistics Division http://data.un.org/CountryProfile.aspx?crName=Russian+Federation\#Economic

World Bank: Russian Federation

http://www.worldbank.org/en/country/russia/overview. 